\title{
Program Kemitraan Masyarakat Melalui Inovasi Panganan Berbahan Dasar Labu Siam Dan Pelatihan E-Commerce Untuk Meningkatkan Ekonomi
}

\section{Community Partnership Program Through Chayote Based Handling Innovation and E-Commerce Training to Improve the Economy}

\author{
${ }^{1}$ Munawarah, ${ }^{1}$ Keumala Hayati, ${ }^{2}$ Delyanti A. Pulungan \\ ${ }^{1}$ Jurusan Akuntansi, Fakultas Ekonomi, Universitas Prima Indonesia \\ ${ }^{2}$ Jurusan Manajemen, Fakultas Ekonomi, Universitas Prima Indonesia \\ Korespondensi: Munawarah, noramunawarah88@gmail.com
}

Naskah Diterima: 14 Agustus 2019. Disetujui: 9 Februari 2020. Disetujui Publikasi: 18 Februari 2020

\begin{abstract}
The purpose of this community development program is to increase the ability and creativity of housewives in creating a product that can later be sold and improve the economy in Lingkungan XI Kelurahan Suka Maju, Kecamatan Medan Johor Sumatera Utara. The team provides training in the form of processing products from chayote to become syrup,candy, jam and chips. In addition to processing products, partners are also introduced and taught how to prepare simple financial reports such as the calculation of cost of goods manufactured, cost of goods sold, and estimated profit and loss to control finances. After the product training process, partners are also taught the marketing process by maximizing technology through digital ecommerce platforms, one of which is shoppe to market their products to be more widely known. The results obtained after the training program show that there is community satisfaction as a partner for the empowerment program. This is also marked by the increased ability of partners in terms of making products from chayote, as well as being able to market it through digital marketing platforms through e-commerce so as to increase sources of income
\end{abstract}

Keywords: Chayote, e-commerce, Medan Johor.

\begin{abstract}
Abstrak. Tujuan dari program kemitraan masyarakat ini adalah untuk meningkatkan kemampuan serta kreatifitas ibu-ibu rumah tangga dalam menciptakan suatu produk yang nantinya dapat dijual dan meningkatkan ekonomi di Lingkungan XI Kelurahan Suka Maju Kecamatan Medan Utara.Tim memberikan pelatihan berupa pengolahan produk dari labu siam untuk dijadikan sirop, permen, selai dan keripik(stick labu). Selain mengolah produk, mitra juga diperkenalkan serta diajarkan cara menyusun laporan keuangan sederhana seperti perhitungan harga pokok produksi, harga pokok penjualan, serta estimasi untung rugi untuk mengontrol keuangan. Setelah proses pelatihan pembuatan produk, mitra juga diajarkan proses marketing dengan memaksimalkan teknologi melalui platform digital e-commerce salah satunya shoppe untuk memasarkan produk mereka agar lebih dikenal luas. Hasil yang diperoleh setelah program pelatihan menunjukkan bahwa adanya kepuasan masyarakat selaku mitra terhadap program pemberdayaan. Hal ini juga ditandai dengan meningkatnya kemampuan mitra dalam hal membuat produk dari labu siam, serta mampu memasarkannya melalui platform digital marketing melalui e-commerce sehingga dapat menambah sumber penghasilan.

Kata Kunci: Labu siam, e-commerce, Medan Johor.
\end{abstract}

\section{Pendahuluan}

Pelaksanaan program pemberdayaan masyarakat melalui inovasi panganan 
berbahan dasar labu siam dan pelatihan e-commerce untuk meningkatkan ekonomi yang dilakukan oleh tim pengusul membidik target mitra atau massa pelatihan masyarakat dari kalangan ekonomi menengah kebawah terkhusus para ibu rumah tangga yang secara ekonomi dan sosial termasuk dalam kategori tidak produktif. Setelah dilakukan survey langsung kepada ibu-ibu rumah tangga di Lingkungan XI Kelurahan Suka Maju Kecamatan Medan Johor Kota Medan, ditemukan fakta bahwa hanya sekitar $20 \%$ dari penduduk wanita yang bekerja di sektor formal, sementara sisanya bekerja disektor non formal seperti tukang cuci, pedagang kaki lima dan termasuk didalamnya hanya berprofesi sebagai ibu rumah tangga. Selanjutnya, tim berhasil mengidentifikasi beberapa permasalahan yang dihadapi oleh mitra seperti tidak memimiliki keterampilan khusus yang dapat untuk menambah penghasilan keluarga. Produktivitas ibu-ibu rumah tangga di Lingkungan XI dalam membantu perekonomian keluarga tergolong rendah salah satunya karena minimnya informasi mengenai penggunaan teknologi dan manfaatnya bagi peningkatan ekonomi. Kurangnya kegiatan yang bertujuan untuk meningkatkan kemandirian ekonomi sebagai akibat minimnya pemahaman dalam memanfaatkan bahan panganan menjadi produk inovatif.

Berdasarkan permasalahan ini, diusulkan program pemberdayaan masyarakat melalui inovasi panganan berbahan dasar labu siam dan pelatihan $e^{-}$ commerce untuk meningkatkan ekonomi. Inovasi menjadi penting mengingat semakin tingginya kebutuhan hidup memaksa setiap individu harus meningkatkan kreatifitasnya dan mendorong minat berbisnis dengan memanfaatkan bahan labu siam untuk dijadikan produk makanan bernilai tambah seperti permen, sirup, selai dan keripik (stick labu). Labu siam (sechium edule) merupakan tanaman suku labu-labuan yang mudah sekali ditemukan di Indonesia. Buah labu siam mengandung vitamin A, vitamin B, dan vitamin C (Asmira \& Arza, 2015). Harga komoditas ini sangat murah sekitar Rp 3000 per kilogram, karena tanaman ini tidak mengenal musim dan proses panen yang singkat. Nantinya setelah diolah menjadi produk yang inovatif, masyarakat dapat menjualnya dengan harga yang lebih tinggi sehingga dapat dijadikan tambahan penghasilan.

Sedangkan untuk media pemasarannya mitra dapat memanfaatkan teknologi digital yaitu melalui e-commerce untuk mempromosikan produk olahannya. Ecommerce adalah proses pembelian, penjualan produk, jasa dan informasi yang dilakukan secara elektronik dengan melibatkan transfer dana elektronik, system manajemen invitory otomatis dan sistem pengumpulan data otomatis yang memanfaatkan jaringan internet computer (Nurmaya, Kurnianingsih, Rosini, \& Diana, 2017) Adapun ruang lingkup dari bisnis E-commerce terbagi tiga yaitu Business to Business (B2B), Business to Consumer (B2C), dan Consumer to Consumer (C2C) (Aswini \& Durai, 2017). Contoh platform digital e-commerce yang terkenal adalah Shoppe, Tokopedia, dan lainnya.

Tujuan kegiatan ini adalah untuk memberikan solusi kepada mitra yaitu kelompok ibu rumah tangga di Lingkungan XI Kelurahan Suka Maju agar lebih produktif dan mampu memanfaatkan bahan-bahan yang ada disekitar. Keberadaan labu jipang dengan harga murah, nantinya dapat diolah menjadi produk bermanfaat dan bernilai jual tinggi. Kegiatan ini diharapkan memberikan manfaat bagi masyarakat karena memiliki life skill untuk mengolah labu siam, sekaligus mendorong jiwa wirausaha mitra agar lebih produktif dan mampu meningkatkan perekonomian masyarakat.

\section{Metode Pelaksanaan}

Tempat dan Waktu. Kegiatan program kemitraan masyarakat dilaksanakan di J1. Suka Terang No.37, Lingkungan XI, Kelurahan Suka Maju, Kecamatan Medan 
Johor Provinsi Sumatera Utara. Kegiatan berlangsung selama kurang lebih 8 bulan mulai dari bulan April-November 2019. Lokasi kegiatan berjarak 10,8 km dari Universitas Prima Indonesia.

Khalayak Sasaran. Sasaran dalam program ini adalah masyarakat khususnya ibu-ibu di Lingkungan XI Kelurahan Suka Maju Kecamatan Medan Johor dengan latar belakang usia produktif dan mayoritas hanya sebagai ibu rumah tangga. Selama ini mitra mengetahui bahwa labu siam hanya diolah sebagai sayuran. Keterbatasan pengetahuan untuk mengolah produk ini karena kurangnya proses pemberdayaan ibu rumah tangga. Padahal potensi pangan ini cukup besar, karena proses panen tidak membutuhkan waktu lama dan biaya yang besar. Hasil panen yang cukup melimpah membuat tanaman ini bernilai rendah di pasar. Harga jual hanya mencapi Rp 3.000/per kilogram. Sehingga tak jarang keberadaanya dianggap sebelah mata karena hanya diolah menjadi sayuran. Terkait hal ini, perlu dilakukan pemberdayaan wanita di lingkungan masyarakat terutama ibu-ibu rumah tangga dan mereka yang bekerja di sektor informal untuk menjadi lebih berdaya guna di masyakarat. Lingkungan XI berada di wilayah Kelurahan Suka Maju, Kecamatan Medan Johor memiliki jumlah penduduk yang cukup besar dengan total mencapai 2000 jiwa. Lebih dari 50\% jumlah penduduk wanita yang sudah berkeluarga bekerja di sektor non formal seperti buruh cuci, pedagang, dan termasuk didalamnya yang hanya sebagai ibu rumah tangga. masyarakat dengan ekonomi menengah kebawah hidup berkelompok dan tinggal di dekat rel kereta api dengan lingkungan yang kurang memadai. Masalah ini dapat dilihat melalui kurangnya kemampuan atau keterampilan masyarakat khususnya wanita dalam bentuk hardskill dan softskill untuk menciptakan suatu produk yang nantinya dapat dijadikan bisnis. Ibu-ibu rumah tangga juga masih kurang produktif dalam membantu perekonomian keluarga. Selain itu, masih banyak ditemukan jenjang pendidikan yang rendah, sejalan dengan kemampuannya menguasai teknologi informasi, sehingga tidak dapat memanfaatkannya menjadi sumber penunjang ekonomi. Perekonomian warga masyarakat yang masih rendah membuat kesulitan untuk berwiraswasta karena tidak memiliki modal yang cukup. Upaya ini diharapkan dapat mendorong peningkatan industri rumah tangga. Menurut Nurmianto \& Nasution, 2004 industri rumah tangga adalah industri yang menggunakan tenaga kerja kurang dari empat orang. Ciri industri ini memiliki modal yang sangat terbatas, tenaga kerja berasal dari anggota keluarga, dan pemilik atau pengelola industri biasanya kepala rumah tangga itu sendiri atau anggota keluarganya. Maka sangatlah tepat program kegiatan ini dilakukan untuk mendorong geliat industri rumah tangga dengan produk inovatif.

Metode Pengabdian. Pelaksanaan kegiatan pengabdian ini dimulai dengan melakukan survey dan pemetaan mitra, sosialisasi hingga pelatihan dan pendampingan mitra. Metode yang diterapkan dapat dijelaskan sebagai berikut :

1. Persiapan pra kegiatan dengan melakukan survey. Survey lapangan ini bertujuan untuk mengetahui aspek-aspek penting dalam mengevaluasi masalah dan kebutuhan mitra di lingkungan XI. Survey atau lengkapnya selfadministered survey adalah metode pengumpulan data primer dengan memberikan pertanyaan-pertanyaan kepada responden individu. Jadi bisa disimpulkan survei adalah metode untuk mengumpulkan informasi dari kelompok yang mewakili sebuah populasi. Dengan bantuan dari Kepala Lingkungan XI, tim dapat memperoleh data-data mengenai sebaran masyarakat terutama ibu-ibu yang tidak bekerja atau hanya bekerja serabutan dan memiliki penghasilan minim.

2. Sosialisasi awal terkait dengan permasalahan yang dialami mitra terkait keterbatasan informasi mengenai pengolahan produk makanan yang berasal dari labu siam sebatas diolah menjadi sayuran seperti sayur bening, opor, ataupun dicampur sambal terasi. Sosialisasi merupakan salah satu metode yang 
melibatkan partisipasi masyarakat dalam menyerap keterampilan yang diberikan dengan cara by doing (Yasser, dkk., 2019). Tim menawarkan alternatif solusi yang dapat dilakukan untuk menciptkan produk inovatif berbahan dasar labu siam. Pemberian modul diharapkan mempermudah tim memahami program pelatihan yang dilaksanakan. Tim juga membantu meliterasi mitra terkait dengan konsep akuntansi dasar dalam hal mengelola keuangannya. Mitra diperkenalkan cara menyusun laporan keuangan sederhana seperti penentuan harga pokok produksi, penyusutan peralatan, harga pokok penjualan, dan laporan laba rugi dari usaha produk labu siam.

3. Pelatihan diawali dengan demo pembuatan produk berbahan dasar labu siam dari tenaga ahli, rincian bahan-bahan baku yang dipergunakan seperti labu siam, gula, tepung terigu, asam sitrat, agar-agar, keju. Alat-alat yang digunakan, teknik mengolah produk dengan lebih efisien, dan mengemas produk lebih menarik. Produk yang akan diolah meliputi pembuatan sirup, keripik (Cheese stick), Selai, dan Permen. Setelah pelatihan pembuatan produk, mitra juga akan diajarkan untuk membuat akun penjualan dengan memanfaatkan platform ecommerece seperti akun shoppe.

4. Pendampingan. Sebagai bentuk keberlanjutan program pelatihan, tim melakukan proses pendampingan kepada mitra kelompok ibu rumah tangga dalam bentuk monitoring progress dan kunjungan langsung ke mitra. Tim melakukan wawancara untuk menggali informasi pada mitra, terkait masalah dan kendala yang dihadapi. Mitra juga akan dibantu dalam membranding produk dengan design serta nama yang unik sehingga mudah menarik pasar.

Indikator Keberhasilan. Berhasil tidaknya kegiatan ini dilaksanakan dapat dilihat dari Indikator capaian program kemitraan masyarakat di Lingkungan XI Kelurahan Suka Maju sebagai berikut:

1. Mitra mampu menciptakan produk inovatif berbahan dasar labu siam, Dalam sekali produksi mitra mampu mengolah $1 \mathrm{~kg}$ Labu jipang menjadi berbagai produk bernilai jual. Misalnya dari $1 / 4 \mathrm{~kg}$ labu siam dapat menghasilkan 6 botol sirup ukuran $100 \mathrm{ml}, 1 / 4 \mathrm{~kg}$ labu siam dapat menghasilkan 6 cup selai, 1/4 labu siam mengasilkan 8 kemasan permen labu siam, dan 1/4 kg labu siam juga dapat menghasilkan 10 kemasan cheese stick dengan berat $100 \mathrm{gr}$.

2. Mitra mampu berkreatifitas dalam menciptakan produk olahan baru dari labu siam, tidak hanya terbatas dari produk yang sudah diajarkan. Produk baru yang berhasil mereka ciptakan adalah kembang loyang, rempeyek, kue talam, lepat dan candil.

3. Mitra mampu memanfaatkan media smartphone sebagai alat pemasaran dengan memiliki akun platform digital marketing shoppe.

4. Pendapatan mitra mulai meningkat ditandai dengan penjualan produk perharinya seperti keripik, rempeyek, dan kembang loyang lebih kurang Rp 200.000.

Metode Evaluasi. Setelah kegiatan selesai, maka tim melakukan evaluasi program pelatihan baik pengolahan produk dan pemasaran produk melalui e-commerce. Evaluasi dapat dilakukan dengan cara mengunjungi mitra serta melakukan wawancara terkait kegiatan yang sudah dilaksanakan. Metode ini juga untuk melihat ada tidaknya perubahan mitra baik sebelum dan sesudah program kemitraan masyarakat ini dilakukan (Rifa'i, dkk., 2017, 2018; Kudsiah, dkk., 2018). Pengamatan langsung (direct observation) oleh tim pelaksana yang mengacu pada indikator keberhasilan dan hasil yang dicapai oleh mitra dengan poin-poin berikut:

1. Sosialisasi

Mitra diharapkan mampu memanfaatkan sumber daya alam untuk diolah menjadi produk bernilai tinggi, dan memahami e-commerce sebagai media pemasaran. Dengana adanya literasi keuangan, mitra diharapkan mampu 
membukukan pengelolaan uang dari setiap proses produksi dan penjualan produk sehingga dapat meminimalisir biaya-biaya yang tidak perlu.

2. Pelatihan

Mampu mengolah produk dengan menggunakan bahan dasar labu siam. Selain itu mitra diharapkan mampu membuat akun media sosial dan akun produk mitra sebagai media pemasaran.

3. Pendampingan

Mitra akan didampingi mulai dari pengemasan, hingga teknik membranding produk hingga lebih menarik minat calon konsumen.

\section{A. Persiapan}

\section{Hasil dan Pembahasan}

Tim melakukan survey ke wilayah Kelurahan Suka Maju Kecamatan Medan Johor sekaligus meminta izin kerjasama dengan kepala Lingkungan XI Ibu Yusnidar BBA. Daerah ini merupakan salah satu wilayah di Kecamatan Medan Johor dengan luas wilayah 2,4 Ha. Secara demografis data jumlah penduduk di wilayah ini mencapai 2.184 jiwa yang terdiri dari 1.129 jiwa penduduk laki-laki dan 1.055 jiwa penduduk perempuan. Jumlah kepala keluarga di lingkungan ini sebanyak 339 kepala keluarga, dan 30 diantaranya yang berdomisili di luar wilayah ini. Dengan komposisi wilayah yang cukup luas, penduduk wilayah ini tersebar dalam berbagai jenis mata pencaharian. Sebanyak 86 kepala keluarga yang bekerja di sektor Pemerintahan dan BUMN, 30 kepala keluarga yang bekerja di perusahaan swasta, 21 kepala keluarga yang berwiraswata, dan sisanya sebanyak 172 kepala keluarga yang bekerja sebagai buruh harian lepas. Artinya lebih dari 50\% masyarakat di wilayah ini yang berada level ekonomi menengah ke bawah. Umumnya mereka tinggal dibekas lintasan rel kereta api dengan kondisi rumah yang kurang memadai. Kondisi ini cukup kontras mengingat secara sebaran tempat tinggal warga yang bertolak belakang dengan warga kelas menengah ke atas. Dari hasil survey tersebut tim akhirnya menetapkan 30 orang sebagai mitra kegiatan sesuai kriteria yang telah ditetapkan. Distribusi karakteristik mitra pelatihan dapat dilihat dari usia, pekerjaan, pendidikan, kepemilikan gadget, serta pengalaman pelatihan.

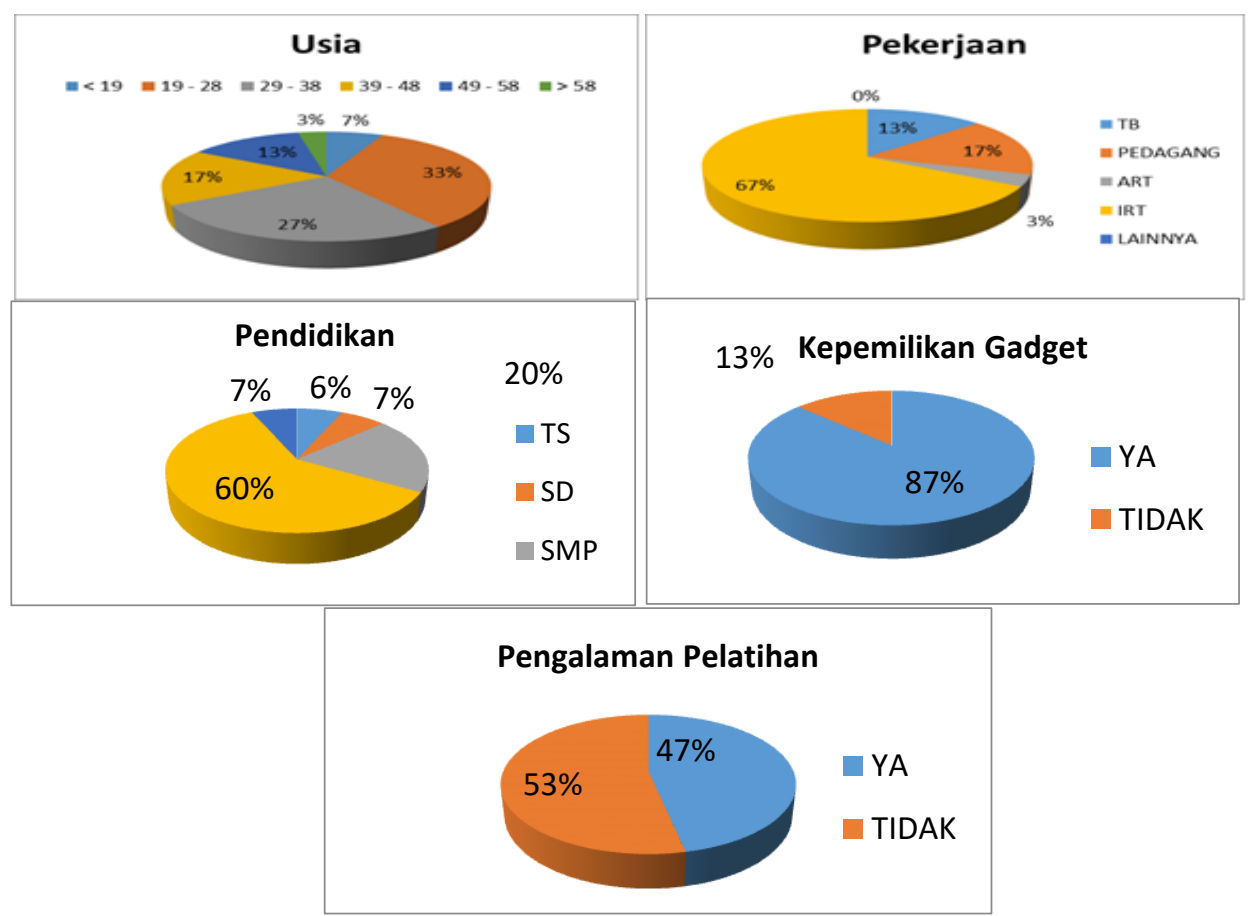

Gambar 1. Distribusi karakteristik mitra 


\section{B. Sosialisasi}

Pengembangan industri rumah tangga dapat berdampak positif terhadap terbukanya lapangan kerja, kesempatan berusaha serta dapat peningkatan pendapatan dan kesejahteraan masyarakat (Nuryanti, 2017). Maka Minimnya informasi serta produktivitas masyarakat di Lingkungan XI dapat diminimalisir dengan memberikan sosialisasi terkait inovasi produk baru bernilai ekonomis (Gambar 1). Mudahnya labu siam ditemui dengan harga sangat murah dapat dimanfaatkan menjadi produk olahan inovatif. Hal ini dapat mendorong terciptanya peluang bisnis karena dapat menambah penghasilan sehinga dapat meningkatkan ekonomi. Memanfaatkan kemajuan teknologi, mitra diperkenalkan dengan digital marketing, sehingga dapat memperluas target pasar melalui media online yang bisa digunakan hanya melalui perangkat Handphone. Mitra juga diedukasi dalam mengelola keuangan usaha, yaitu dengan menyusun laporan keuangan sederhana seperti penentuan harga pokok produksi, penyusutan peralatan, harga pokok penjualan, perhitungan BEP dari setiap transaksi penjualan diperoleh dalam waktu 1 bulan produksi, hingga laporan laba rugi dari usaha produk labu siam.

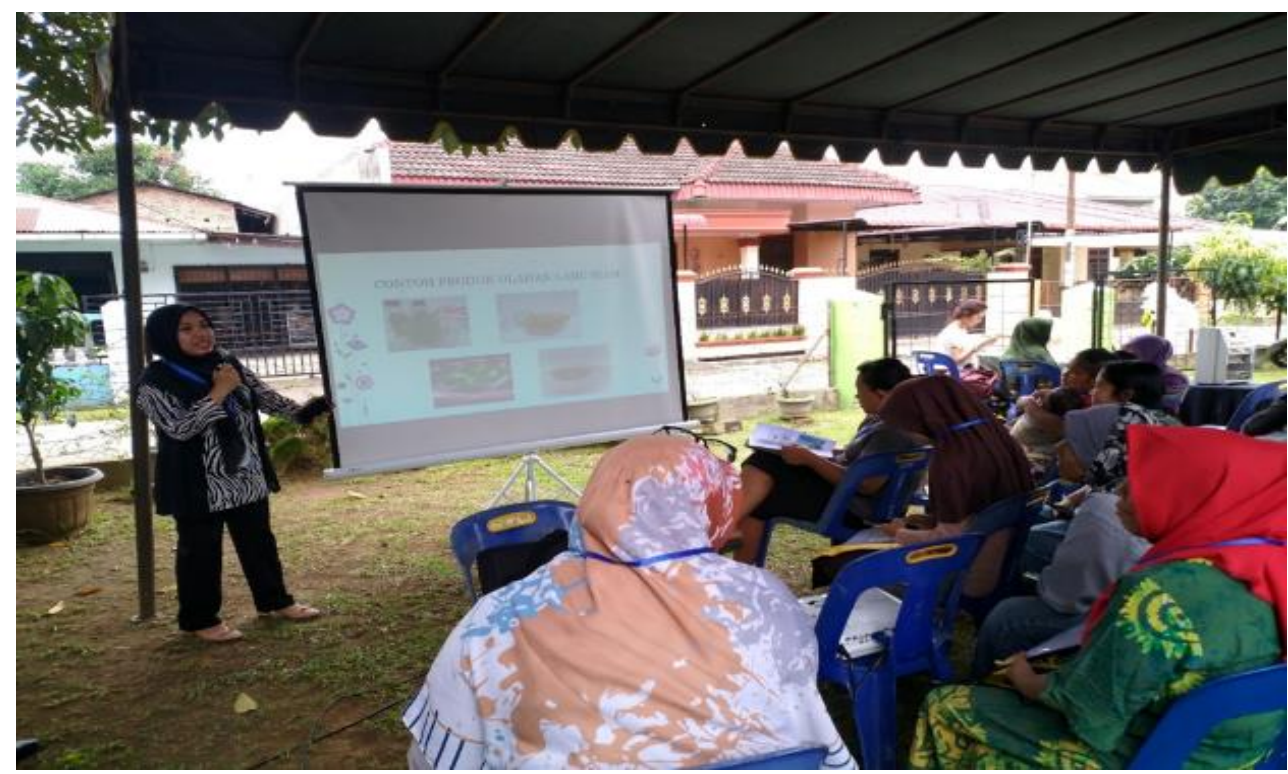

Gambar 2. Sosialisasi mitra

\section{Pelatihan}

Dalam tahapan ini tim pelaksana juga memberikan modul pelatihan baik pelatihan membuat inovasi produk makanan berbahan labu siam dan pelatihan membuat e-commerce. Proses pelatihan akan dibagi menjadi dua tahapan. Tahapan pertama adalah demo pembuatan produk makanan berbahan dasar labu siam diolah menjadi sirop, permen, keripik, dan selai oleh tenaga ahli (Gambar 3). Untuk pertemuan berikutnya, tim pengusul mempersiapkan bahan yang dibutuhkan untuk proses pelatihan kepada mitra. Adapun bahan yang digunakan adalah labu siam, gula, garam, pewarna makanan,asam sitrun, tepung terigu, tepung kanji, santan, telur, agar-agar, dan keju. Mitra langsung mempraktikkan cara pembuatan produk olahan tersebut sekaligus mengemas produk agar lebih menarik minat calon konsumen.

Tahapan berikutnya dari program ini adalah penerapan e-commerce sebagai sarana pemasaran dan penjualan olahan produk berbahan dasar labu siam. Penerapan tersebut dilakukan dengan pelatihan e-commerce meliputi beberapa langkah diantaranya pembuatan e-mail (surat elektronik) mitra sebagai salah satu syarat utama memasuki dunia digital, pembuatan akun media sosial berbasis bisnis mitra, pembuatan akun produk mitra pada jejaring online shop nasional 
seperti Shopee, serta aktivasi dan pemeliharaan akun media sosial dan akun produk mitra (Gambar 4).

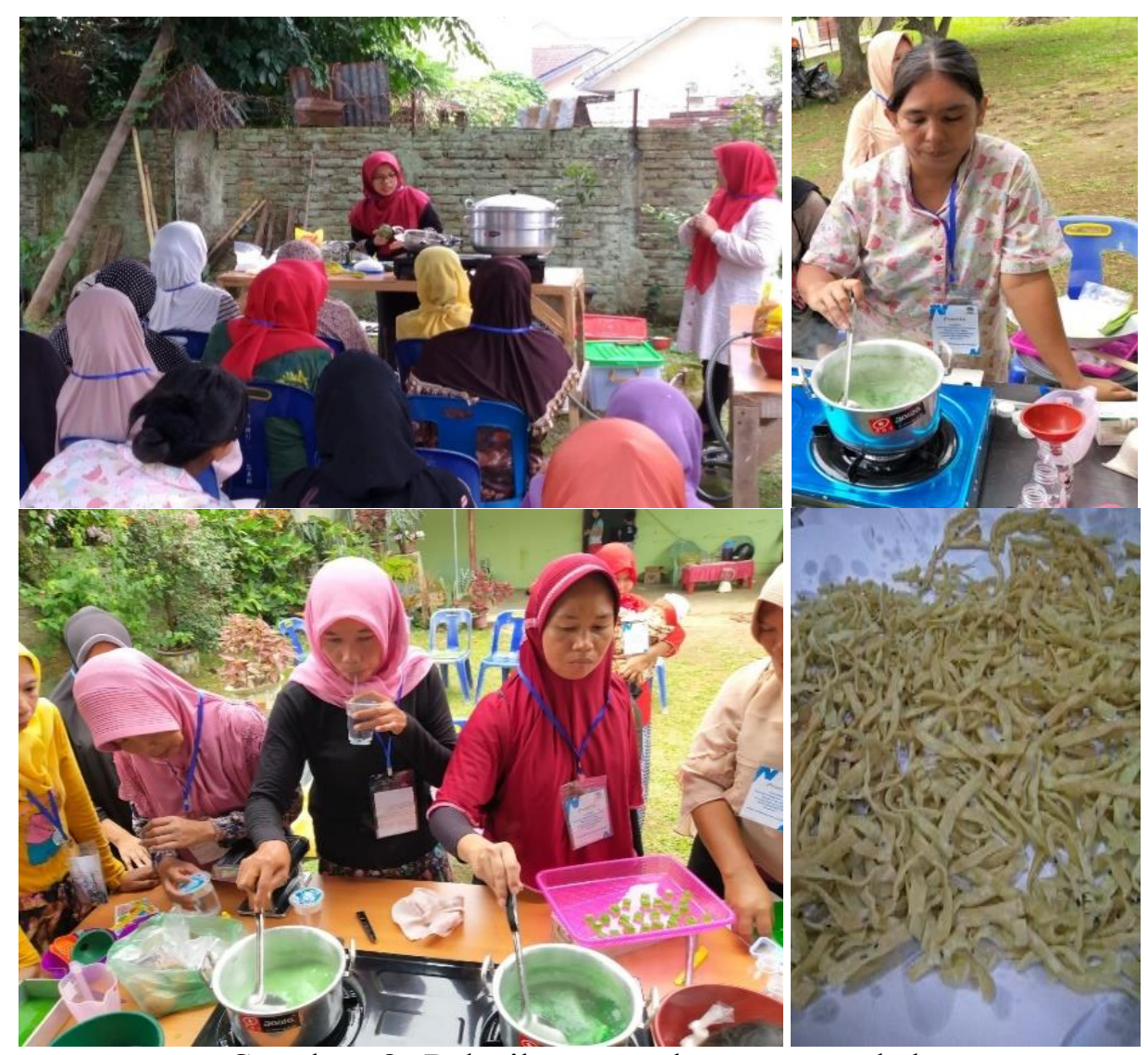

Gambar 3. Pelatihan pembuatan produk
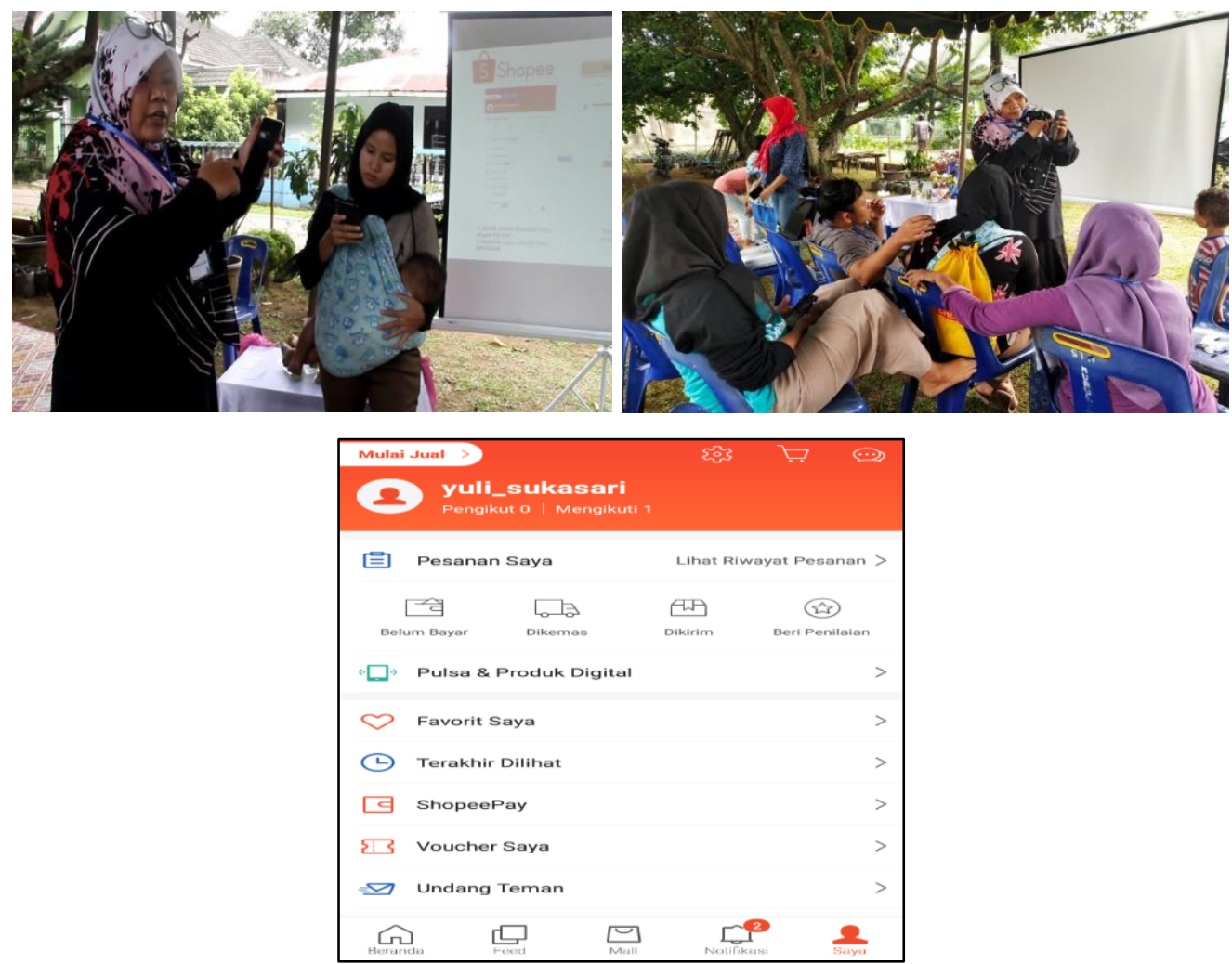

Gambar 4. Pelatihan pembuatan akun produk mitra

Jurnal Panrita Abdi, 2020, Volume 4, Issue 2. 


\section{Pendampingan}

Sebagai bentuk monitoring dan evaluasi setelah kegiatan pelatihan, tim melakukan kunjungan ke rumah mitra. Dari hasil kunjungan diperoleh hasil bahwa kemampuan mitra Kemampuan mitra meningkat terlihat dari mampu membuat olahan produk berbahan dasar labu siam seperti selai, permen, sirop, dan keripik (stick labu). Berdasarkan hasil wawancara dengan salah satu peserta dalam kegiatan evaluasi, mereka dapat memodifikasi bahan-bahan tidak hanya terpaku pada resep yang sudah diberikan dan sesuai selera. Mitra bisa lebih kreatif untuk menciptakan produk makanan baru dari labu siam ini, mengingat mudahnya bahan ini ditemui dengan harga yang sangat murah dan jumlah yang banyak.

Tim juga membantu membranding produk dengan menciptakan merk dagang "Mak Elpa" yang merupakan singkatan dari makanan labu jipang (Gambar 5). Dengan desaign unik, dan nama yang menarik perhatian diharapkan mempermudah produk mereka cepat diterima dimasyarakat. Berdasarkan hasil pengamatan diperoleh bahwa ada beberapa mitra yang sudah mulai memasarkan produknya melalui media online.

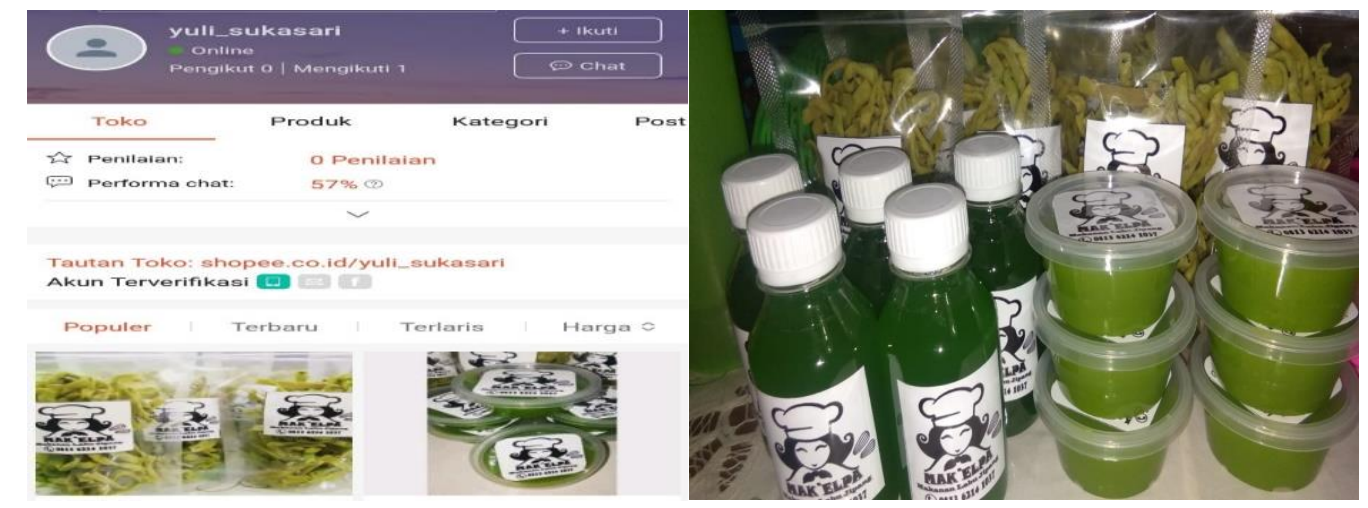

Gambar 5. Pendampingan pemasaran produk mitra

\section{E. Keberhasilan Kegiatan}

Keberhasilan kegiatan ini dapat ditandai dengan meningkatkanya produktivitas dan kreatifitas mitra di Lingkungan XI (Gambar 6). Kreativitas tersebut ditandai melalui kemampuan berinovasi dengan menciptakan kembang loyang, dan rempeyek dari campuran bahan labu siam. Bahkan mitra berencana juga untuk membuat lepat dan candil melalui bahan labu siam ini. Mereka juga mulai berinovasi dengan rasa dan bentuk produk seperti permen sehingga lebih menarik minat konsumen. Hasil ini ternyata menarik minat pembeli dari warga sekitar lingkungan mitra, artinya dapat dikatakan inovasi produk ini juga diterima oleh konsumen. Lambat laun diharapkan produk ini dapat diproduksi massal dengan merk dagang yang telah dibantu didesign oleh tim pengabdian masyarakat.

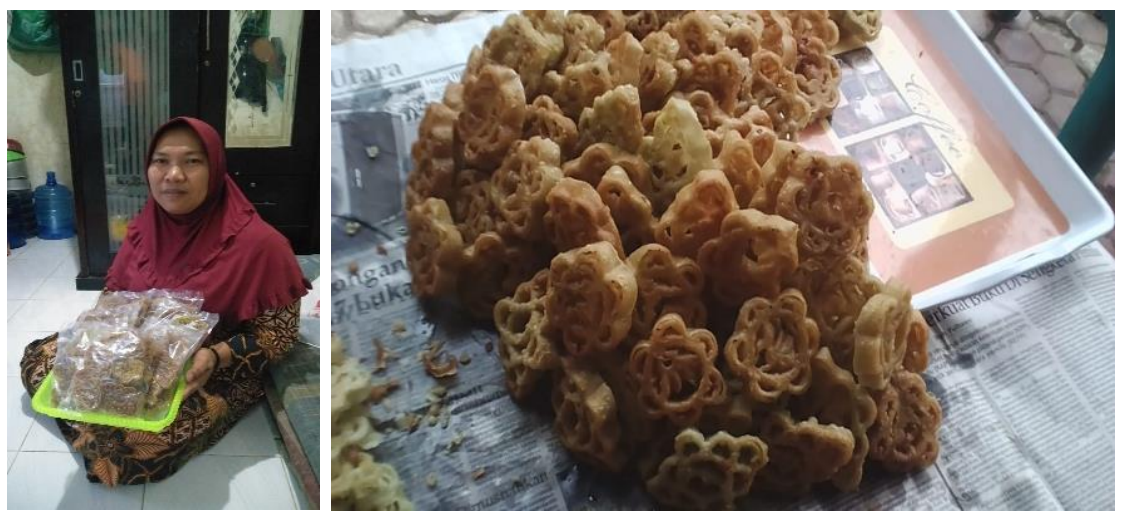

Gambar 6. Inovasi Produk Mitra 
Meningkatnya produktivitas ini dari sisi ekonomis menjadi sumber penghasilan tambahan bagi mitra. Dari $1 / 4 \mathrm{~kg}$ labu siam dapat menghasilkan 6 botol sirup ukuran $100 \mathrm{ml}$ dengan total biaya tak lebih dari Rp 11.000. Untuk membuat 1 botol sirup hanya membutuhkan modal Rp 1.700an dapat dijual menjadi Rp $5.000,-$ sampai Rp 8.000,- per botolnya. Begitu pula dengan pembuatan selai labu siam hanya membutuhkan modal tidak kurang dari Rp 5.000,-, dan dapat dijual ke pasar dengan harga Rp 12.000 per kemasan. Dalam setiap produksi hanya membutuhkan $1 \mathrm{~kg}$ labu siam dapat menghasilkan total 30 kemasan produk. Dalam 1 bulan terdapat 15 kali produksi atau sebanyak 450 kemasan. Perhitungan BEP (Break Even Point) dari setiap transaksi penjualan diperoleh dalam waktu 1 bulan produksi, dimana dalam setiap $15 \times$ kegiatan produksi, dapat menjual 450 kemasan dengan keuntungan Rp 1.136.855 dengan modal awal Rp 1,093,905.

Pemanfaatan gadget tidak hanya sebagai alat komunikasi namun juga bisa dijadikan sumber penghasilan. Pemanfaatan media online melalui pelatihan $e$ commerce membuat ibu-ibu dilingkungan ini mampu membuat akun jual beli online salah satunya Shoppee (Gambar 7). Sebagai salah satu akun yang paling mudah, dan banyak memberikan promo tentunya memberikan keuntungan bagi mereka. Faktanya, proses jual beli online ini mampu merangkul pasar lebih luas, tidak hanya disekitaran wilayah Medan Johor. Terlihat dari salah satu akun mitra yang berhasil melakukan penjualan dengan menjaring pembeli yang berasal dari wilayah luar seperti Medan Sunggal.

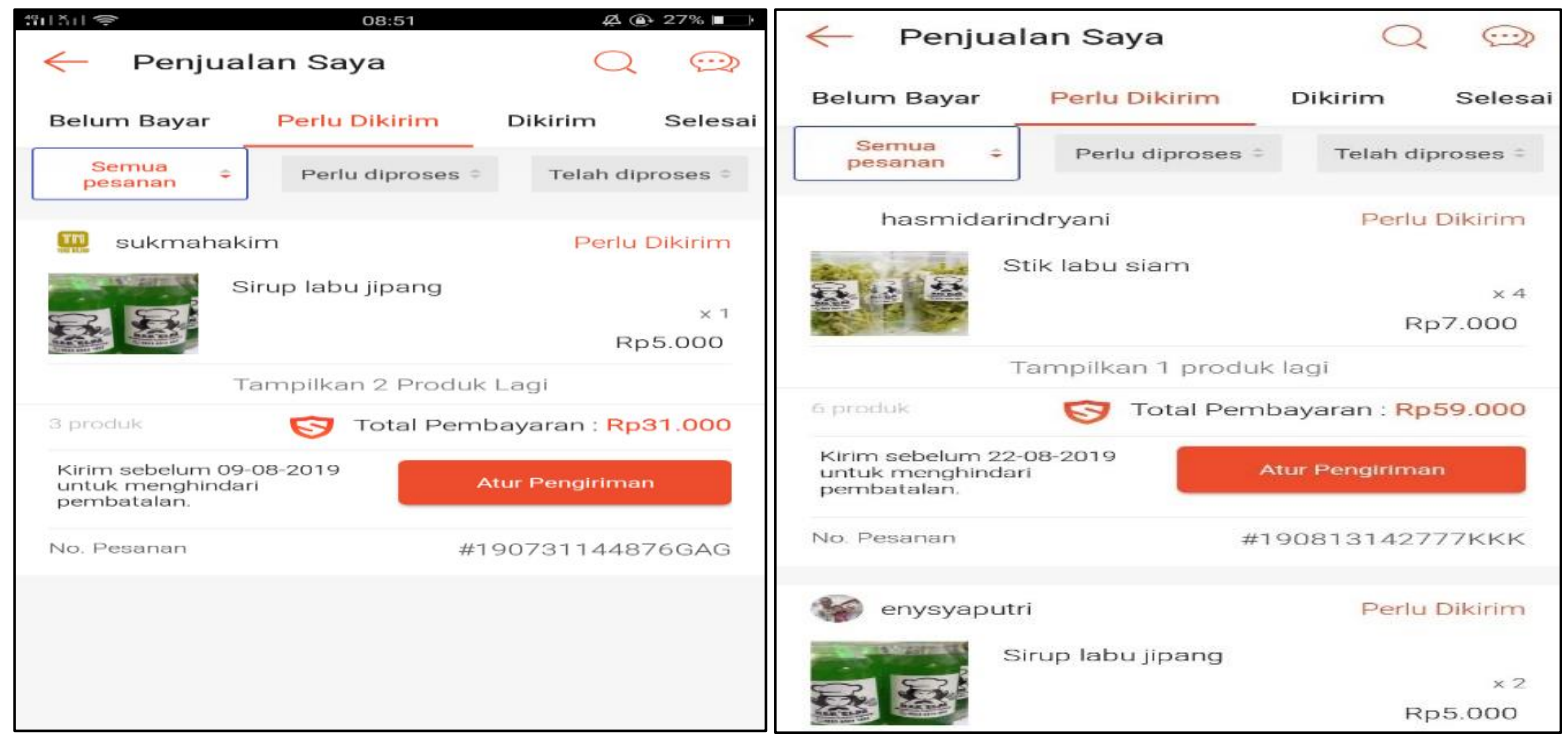

Gambar 7. Penjualan Produk Mitra melalui Shopee

\section{Kesimpulan}

Program kemitraan masyarakat di Lingkungan XI Kelurahan Suka Maju Kecamatan Medan Johor dapat dikatakan berhasil dalam menyelesaikan masalah minimnya kemampuan berinovasi mitra menciptakan produk dengan memanfaatkan bahan yang ada disekitar lingkungan untuk meningkatkan ekonomi. Mitra telah mampu memanfaatkan komoditas lokal labu siam untuk dimodifikasi menjadi panganan bernilai jual tinggi dengan proses sederhana namun rasanya lezat seperti sirup, permen, selai, keripik, rempeyek, kembang loyang dan lainnya. Mitra juga telah mengenal teknik penjualan e-commerce dengan memanfaatkan keberadaan perangkat smartphone sebagai media pemasaran paling mudah dan efektif. Maka secara keseluruhan dapat disimpulkan terjadi peningkatan ekonomi mitra. 


\section{Ucapan Terima Kasih}

Penulis mengucapkan Terima Kasih kepada DRPM Kementrian Riset Teknologi dan Pendidikan Tinggi Republik Indonesia yang telah memberikan dana hibah pada Program Kemitraan Masyarakat dengan nomor kontrak T/63/L1.3.1/PT.01.03/ 2019 dan kepada kepala lingkungan XI serta warga masyarakat di Kelurahan Suka Maju Kecamatan Medan Johor.

\section{Referensi}

Asmira, S., \& Arza, P.A. (2015). Pengaruh Penggunaan Labu Siam dengan Konsentrasi yang Berbeda terhadap Mutu Organoleptik dan Kadar Serat kerupuk Ikan. Jurnal Stikes Perintis, 2(2), 38-46.

Aswini, K. \& Durai, R.V. (2017). Trust in E-Commerce. Imperial Journal of Interdisciplinary Research (IJIR), 3(5), 1637-1639.

Kudsiah, H., Tresnati, J., \& Ali , S. A. (2018). IbM Kelompok Usaha Bandeng Segar Tanpa Duri di Kabupaten Pangkep Sulawesi Selatan. Panrita Abdi Jurnal, 2(1), 55-63.

Nurmaya, K., Rosini, I., \& Diana, N.E. (2017). Ibm Pelatihan Decoupage Dan ECommerce Untuk Meningkatkan Ekonomi Ibu Rumah Tangga. In S. Suryanto (Ed.), Prosiding Seminar Hasil Pengabdian Kepada Masyarakat (SNP2M) 2017: Vol. (pp. 160-165). Retrieved from http://snp2m2017.poliupg.ac.id/prosidingsnp2m2017/

Nurmianto, E., \& Nasution, A.H. (2004). Perumusan Strategi Kemitraan Menggunakan Metode Ahp Dan Swot (Studi Kasus Pada Kemitraan PT. INKA Dengan Industri Kecil Menengah di Wilayah Karesidenan Madiun). Jurnal Teknik Industri, 6(1), 47-60. https://doi.org/10.9744/jti.6.1.pp.47-60

Nuryanti, D.M.I. (2017). Program Kemitraan Masyarakat (PKM) Pengembangan Usaha Peyek Kacang Di Kota Palopo. In S. Suryanto (Ed.), Prosiding Seminar Hasil Pengabdian Kepada Masyarakat (SNP2M): Vol. (pp. 351-356). Makassar: Unit Penelitian dan Pengabdian Kepada Masyarakat Politeknik Negeri Ujung Pandang.

Rifa'i, M.A., Kudsiah, H., \& Muzdalifah. (2017). Alih teknologi produksi benih anemon laut secara aseksual. Jurnal Panrita Abdi, 1(1), 33-39.

Rifa'i, M.A., Syahdan, M., Muzdalifah, \& Kudsiah, H. (2018). Pengembangan Usaha Produk Intelektual Kampus: Anemon Laut Ornamen. Jurnal Panrita Abdi, 2(1), 40-47.

Yasser, M., Asfar, A.M.I.A., Asfar, A.M.I.T., Rianti, M., \& Budianto, E. (2019). Pengembangan Produk Olahan Gula Merah Tebu dengan Pemanfaatan Ekstrak Herbal di Desa Latellang Kabupaten Bone. Panrita Abdi, 3(2), 97-104. Retrieved from http://journal.unhas.ac.id/index.php/panritaabdi

Penulis:

Munawarah, Jurusan Akuntansi, Fakultas Ekonomi, Universitas Prima Indonesia, Medan.

E-mail: noramunawarah88@gmail.com

Keumala Hayati, Jurusan Akuntansi, Fakultas Ekonomi, Universitas Prima Indonesia, Medan. Email: keumalahayatihakim@gmail.com

Delyanti A.Pulungan, Jurusan Manajemen, Fakultas Ekonomi, Universitas Prima Indonesia, Medan.

E-mail: delyanti.pulungan@gmail.com

Bagaimana men-sitasi artikel ini:

Munawarah,M., Hayati,K., \& Pulungan,D.A. (2020). Inovasi Panganan Berbahan Dasar Labu Siam dan Pelatihan E-Commerce untuk Meningkatkan Ekonomi. Jurnal Panrita Abdi, 4(2), 136 -145. 